\title{
WILDLIFE HELMINTH RISK IN RADOM NATIONAL PARK; SOUTH DARFUR STATE, SUDAN
}

\author{
ABUESSAILLA, A.A. ; ISMAIL, A.A. ${ }^{* *}$ and AGAB, H. ${ }^{* * *}$ \\ *Ministry of Animals Resources and Fisheries, South Darfur State. E.mail: atifabuessailla@yahoo.com. \\ ** Department of Pathology, Parasitology and Microbiology, College of Veterinary Medicine, Sudan University of Science \\ and Technology, Khartoum North, Sudan. \\ *** Department of Fisheries and Wildlife Science, College of Animal Production Science and Technology, Sudan University \\ of Science and Technology, Khartoum, Sudan. Email: hamidagab1@,hotmail.com
}

\section{ABSTRACT}

Received at: 11/2/2014

Accepted: 9/4/2014

\begin{abstract}
This paper describes the results of a survey of the gastro-intestinal helminth parasites in the faecal matters of fourteen wildlife species investigated in five sites in Radom National Park (R.N.P.), South Darfur State, Sudan. These sites were Radom area, Alhufra, Titrbi, Kafindibei and Kafiakingi. Out of 579 faecal matters examined, 177 were found containing eggs of helminth parasites with an overall prevalence of $30.6 \%$. The Aardvark (Orycteropus afer) had the highest overall infection rate of helminth eggs $(60 \%)(9 / 15)$, while the Patas monkey (Erythrocebus patas) showed the lowest prevalence (2.7\%) (1/37). The helminth parasites recorded throughout this study included Ascaris spp., Trichuris spp., Haemonchus spp., Oesophagostomum spp., Toxocara spp., Trichostrongylus spp., Strongyloides spp., Moniezia spp. and Coccidia oocysts. Kafiakingi area showed the highest prevalence $(35.9 \%)(65 / 181)$, followed by Kafindibei area $(35.1 \%)$ (34/97) while Alhufra area showed the lowest prevalence (17.6\%) (13/74). The results of this survey were compared and discussed with previous findings of similar studies conducted in Sudan and elsewhere.
\end{abstract}

Key words: Helminth parasites, Wildlife, Radom National Park, South Darfur State, Sudan.

\section{INTRODUCTION}

The available information on parasitic infection among wildlife species, particularly in Sudan, is scanty. There are few scattered papers published in scientific journals among which is the pilot work of Eisa et al. (1979) which contained a check-list of helminth parasites recorded in domestic and wild animals in Sudan during the period 1902 1975. According to these authors, Cysticercus tenuicollis was reported in the reedbuck, monkey and kob; Cysticercus pisiformis in the rabbit; Trichuris spp. was reported in the monkey and gazelle; Toxocara canis was reported in cheetah and wild cat; Setaria labiotopapillosus in the reedbuck; Trichostrongylus spp. in the giraffe; Ascaris lumbricoides in the wild pig; Strongyloid spp. in the gazelle; Ascaris pythonis in the python and Toxascaris leonina in the lion. All the investigated faecal matters for the above mentioned findings were collected from wildlife species kept in captivity at Khartoum Zoo. Saad and Eisa (1980) surveyed the parasites of seven hussar monkeys in which they reported the presence of three helminthes, namely; Streptophagus pigmentatus, Oesophagostomum biforcum and Trichuris trichura. The same authors noticed that, although some wild mammals were infected by endoparasites, however, they did not show clinical evidence of disease and health deviation despite the presence of these parasites. In another work, laboratory examination of 184 faecal samples belonging to 44 species of wild animals kept at Khartoum Zoo (Sudan) revealed the presence of Trichostrongylus eggs in faeces of dorcas gazelles, cheetah, roan antelope, giraffe, red-fronted gazelles, Nubis baboons, vervet monkeys and cape buffaloes (Saad et al., 1983). Free-ranging wild animals in Sudan were investigated for the prevalence of helminth parasites only once in Dinder National Park (D.N.P.) (Sayied and Agab, 2009).

The present study is intended to investigate the prevalence of helminth parasite in wildlife in Radom National Park.

\section{MATERIALS and METHODS}

Study Areas: The Radom National Park is located to the south-west of Lake Kundi on the border with the Central African Republic, in the south-western corner of Southern Darfur Region, Sudan. The park consists of an area of broken hilly country lying between two 
main rivers, the Adda and the Umbelasha. Radom was declared a Biosphere Reserve in 1979 by the International Union for Conservation of Nature (IUCN) (1987). The vegetation is principally savannah woodland dominated by Terminalia brownii, Combretum spp., Anogeissus leiocarpus and Isoberlinia doka trees.

Collection and laboratory examination of faecal samples: A total of 579 faecal samples were collected from the five sites in the Radom National Park, namely; Radom area, Alhufra, Titrbi, Kafindibei and Kafiakingi. The samples were collected from 14 wildlife species. The collected faecal samples were put in labeled nylon bags and mixed with $10 \%$ formaldehyde solution and then transported to the laboratory in Nyala for examination. In the laboratory, two qualitative techniques, namely the floatation and sedimentation techniques were used in for separation, concentration and demonstration of parasite eggs and oocysts in the collected faecal samples. Both techniques were done following the method described by FAO (2006).

Results of the laboratory examination were analyzed using Chi-square analysis.

\section{RESULTS}

Frequencies and distributions of the tested samples by species and area are presented in Table 1. The Dikdik (Madaqua guentheri) represented the highest sampled animal (101/579) (17.4\%) while the bushbuck $(11 / 579)(1.9 \%)$ represented the lowest sampled species (Table1).

Table 1: Frequency and distribution of tested faecal samples of wildlife species and area of faecal collection for internal parasites in Radom National Park, South Darfur State, Sudan.

\begin{tabular}{lcc}
\hline Factor and its level & Tested samples (No.) & Tested samples (\%) \\
\hline Number of faecal samples & 579 & 100 \\
\hline Species: & 75 & 13 \\
Warthog & 83 & 14.3 \\
Baboons & 37 & 6.4 \\
Patas monkey & 35 & 6 \\
Vervet monkey & 12 & 2.1 \\
Leopard & 17 & 2.9 \\
Reedbuck & 27 & 4.7 \\
Cheetah & 15 & 2.6 \\
Aardvark & 101 & 17.4 \\
Dikdik & 69 & 11.9 \\
Rabbit & 41 & 7.1 \\
Fox & 34 & 5.9 \\
Spotted hyaena & 11 & 1.9 \\
Bushbuck & 22 & 3.8 \\
Waterbuck & & \\
\hline Area: & & \\
Radom area & 158 & 27.3 \\
Alhufra & 74 & 12.8 \\
Titrbi & 69 & 11.9 \\
Kafindibei & 97 & 16.8 \\
Kafiakingi & 181 & 3.13 \\
& & \\
\hline Total & 579 & 100 \\
\hline
\end{tabular}

The overall prevalence of helminth parasites in the different species investigated in this study was found to be $30.6 \%(177 / 579)$ (Table 2).

According to the species of wildlife, the aardvark (Orycteropus afer) had the highest prevalence of internal parasites infection (9/15) (60\%), whereas the spotted hyaena (Crocota crocota) showed the lowest prevalence $(1 / 34)(2.9 \%)$ as presented in Table 2 .

According to the area of sample collection, Kafiakingi showed the highest prevalence of internal parasites $(35.9 \%)(65 / 181)$, followed by Kafindibei area (35.1\%) (34/97), while Alhufra area showed the lowest prevalence $(17.6 \%)(13 / 74)$ (Table 2). 
Table 2: Prevalence of internal parasites by species and area in Radom National Park, South Darfur State, Sudan.

\begin{tabular}{|c|c|c|c|c|}
\hline $\begin{array}{c}\text { Factor and its } \\
\text { levels }\end{array}$ & $\begin{array}{c}\text { Number of tested } \\
\text { samples }\end{array}$ & $\begin{array}{c}\text { Number of positive } \\
\text { samples }\end{array}$ & Prevalence $(\%)$ & $\begin{array}{c}\text { 95\% CI } \\
\text { Lower - Upper }\end{array}$ \\
\hline Wildlife species & 579 & 177 & 30.6 & $26.85-34.35$ \\
\hline \multicolumn{5}{|l|}{ Species: } \\
\hline Warthog & 75 & 33 & 44 & $32.77-55.23$ \\
\hline Baboons & 83 & 21 & 25.3 & $15.95-34.65$ \\
\hline Patas monkey & 37 & 7 & 18.9 & $6.28-31.52$ \\
\hline Vervet monkey & 35 & 11 & 31.4 & $16.02-46.78$ \\
\hline Leopard & 12 & 2 & 16.7 & $-4.4-37.8$ \\
\hline Reedbuck & 17 & 6 & 35.3 & $12.58-58.02$ \\
\hline Cheetah & 27 & 3 & 11.1 & $-0.75-22.95$ \\
\hline Aardvark & 15 & 9 & 60 & $35.21-84.79$ \\
\hline Dikdik & 101 & 35 & 34.7 & $25.42-43.98$ \\
\hline Rabbit & 69 & 30 & 43.5 & $31.8-55.2$ \\
\hline Fox & 41 & 6 & 14.6 & $3.79-25.41$ \\
\hline Spotted hyaena & 34 & 1 & 2.9 & $-2.74-8.54$ \\
\hline Bushbuck & 11 & 5 & 45.5 & $16.07-74.93$ \\
\hline Waterbuck & 22 & 8 & 36.4 & $16.29-56.51$ \\
\hline Area: & & & & \\
\hline Radom area & 158 & 49 & 31 & $23.79-38.21$ \\
\hline Alhufra & 74 & 13 & 17.6 & $8.92-26.28$ \\
\hline Titrbi & 69 & 16 & 23.2 & $13.24-33.16$ \\
\hline Kafindibei & 97 & 34 & 35.1 & $25.6-44.6$ \\
\hline Kafiakingi & 181 & 65 & 35.9 & $28.91-42.89$ \\
\hline Total/Overall & 579 & 177 & 30.6 & $26.85-34.35$ \\
\hline
\end{tabular}

Out of all the internal parasites identified in the present study, Moniezia spp. recorded the highest prevalence rate (13.3\%), followed by Coccidia spp. (12.1\%) and finally Trichuris spp. (5.2\%).

For Trichuris infection per wildlife species, the baboons (Papio cynocephalus) had the highest prevalence (25.3\%) (21/83), with 95\% CI \pm 9.35 , while Patas monkeys (Erythrocebus patas) showed the lowest prevalence (10.8\%) (4/37), with 95\% CI \pm 10 (Table 3). For Trichuris infection per site, Radom area showed the highest prevalence $(7.6 \%)(12 / 158)$, with $95 \% \mathrm{CI} \pm 4.13$, while Titrbi showed the lowest prevalence $(2.9 \%)(2 / 69)$, with $95 \%$ CI \pm 3.96 . The proportions of positive results of Trichuris infection differed between species and area. In the univariate analysis using chi-square, species was significantly ( $p$-value $=0.000)$ associated with floatation and sedimentation methods of identification for Trichuris infection. However, area was not significantly associated $(\mathrm{p}$-value $=0.547)$ with floatation and sedimentation methods of identification regarding Trichuris infection. 
Table 3: Univariate associations of factors with Trichuris infection positivity in Radom National Park, South Darfur State, Sudan.

\begin{tabular}{|c|c|c|c|c|c|c|c|}
\hline $\begin{array}{l}\text { Risk Factors } \\
\text { With levels }\end{array}$ & $\begin{array}{c}\text { No. of } \\
\text { tested } \\
\text { Samples }\end{array}$ & $\begin{array}{c}\text { No. of } \\
\text { positive } \\
\text { Samples }\end{array}$ & $\begin{array}{c}\text { \%Positive } \\
\text { (Prevalence) }\end{array}$ & $\begin{array}{c}95 \% \\
\text { CI }\end{array}$ & d.f. & $X^{2}$ & P. value \\
\hline \multicolumn{8}{|l|}{ Types: } \\
\hline Wildlife & 579 & 30 & 5.2 & \pm 1.81 & 1 & 31.900 & 0.000 \\
\hline Species: & & & & & 17 & 229.722 & 0.000 \\
\hline Warthog & 75 & 0 & 0 & 0 & & & \\
\hline Baboons & 83 & 21 & 25.3 & \pm 9.35 & & & \\
\hline Patas monkey & 37 & 4 & 10.8 & \pm 10 & & & \\
\hline Velvet monkey & 35 & 5 & 14.3 & \pm 11.6 & & & \\
\hline Leopard & 12 & 0 & 0 & 0 & & & \\
\hline Reedbuck & 17 & 0 & 0 & 0 & & & \\
\hline Cheetah & 27 & 0 & 0 & 0 & & & \\
\hline Aardvank & 15 & 0 & 0 & 0 & & & \\
\hline Dikdik & 101 & 0 & 0 & 0 & & & \\
\hline Rabbit & 69 & 0 & 0 & 0 & & & \\
\hline Fox & 41 & 0 & 0 & 0 & & & \\
\hline Spotted hyaena & 34 & 0 & 0 & 0 & & & \\
\hline Bushbuck & 11 & 0 & 0 & 0 & & & \\
\hline Waterbuck & 22 & 0 & 0 & 0 & & & \\
\hline Area: & & & & & 4 & 3.068 & 0.547 \\
\hline Radom area & 352 & 12 & 3.4 & \pm 1.89 & & & \\
\hline Alhufra & 129 & 4 & 3.1 & \pm 2.99 & & & \\
\hline Titrbi & 184 & 2 & 1.1 & \pm 1.51 & & & \\
\hline Kafindibei & 225 & 6 & 2.7 & \pm 2.12 & & & \\
\hline Kafiakingi & 289 & 6 & 2.1 & \pm 1.65 & & & \\
\hline
\end{tabular}

For the prevalence of Moniezia by wildlife species, the warthog (Phacochoerus aethiopicus) showed the highest prevalence (44\%) (33/75), with 95\% CI \pm 11.23 , while the vervet monkeys (Cercopithecus aethiops) showed the lowest prevalence (5.7\%) (2/35) (Table 4), with 95\% CI \pm 7.68 . Area-wise, the prevalence of Moniezia was highest in Kafiakingi (16.6\%) (30/181), with 95\% CI \pm 5.42 , while Alhufra showed the lowest prevalence (5.4\%) (4/74), with $95 \% \mathrm{CI} \pm 5.15$. In the univariate analysis using chi square, species was significantly associated (pvalue $=0.000$ ) with floatation and sedimentation methods while the area of sample collection was not significantly associated ( $\mathrm{p}$-value $=0.391$ ) with floatation and sedimentation methods of identification regarding Moniezia infection. 
Assit Vet. Med. J. Vol. 60 No. 141 April 2014

Table 4: Univariate associations of factors with Moniezia infection positivity in Radom National Park, South Darfur State, Sudan.

\begin{tabular}{|c|c|c|c|c|c|c|c|}
\hline $\begin{array}{l}\text { Risk Factors } \\
\text { With levels }\end{array}$ & $\begin{array}{c}\text { No. of } \\
\text { tested } \\
\text { Samples }\end{array}$ & $\begin{array}{c}\text { No. of } \\
\text { positive } \\
\text { Samples }\end{array}$ & $\begin{array}{c}\% \text { Positive } \\
\text { (Prevalence) }\end{array}$ & $95 \%$ CI & d.f & $X^{2}$ & P. value \\
\hline \multicolumn{8}{|l|}{ Types: } \\
\hline Wildlife & 579 & 77 & 13.3 & \pm 2.77 & 1 & 16.241 & 0.000 \\
\hline Species: & & & & & 17 & 180.932 & 0.000 \\
\hline Warthog & 75 & 33 & 44 & \pm 11.23 & & & \\
\hline Baboons & 83 & 0 & 0 & 0 & & & \\
\hline Patas monkey & 37 & 3 & 8.1 & \pm 8.79 & & & \\
\hline Velvet monkey & 35 & 2 & 5.7 & \pm 7.68 & & & \\
\hline Leopard & 12 & 2 & 16.7 & \pm 21.1 & & & \\
\hline Reedbuck & 17 & 0 & 0 & 0 & & & \\
\hline Cheetah & 27 & 3 & 11.1 & \pm 11.85 & & & \\
\hline Aardvank & 15 & 5 & 33.3 & \pm 23.85 & & & \\
\hline Dikdik & 101 & 7 & 6.9 & \pm 4.94 & & & \\
\hline Rabbit & 69 & 17 & 24.6 & \pm 10.16 & & & \\
\hline Fox & 41 & 3 & 7.3 & \pm 7.96 & & & \\
\hline Spotted hyaena & 34 & 0 & 0 & 0 & & & \\
\hline Bushbuck & 11 & 0 & 0 & 0 & & & \\
\hline Waterbuck & 22 & 2 & 9.1 & \pm 12.02 & & & \\
\hline$\underline{\text { Area: }}$ & & & & & 4 & 4.116 & 0.391 \\
\hline Radom area & 352 & 35 & 9.9 & \pm 3.12 & & & \\
\hline Alhufra & 129 & 7 & 5.4 & \pm 3.9 & & & \\
\hline Titrbi & 184 & 16 & 8.7 & \pm 4.07 & & & \\
\hline Kafindibei & 225 & 24 & 10.7 & \pm 4.04 & & & \\
\hline Kafiakingi & 289 & 33 & 11.4 & \pm 3.66 & & & \\
\hline
\end{tabular}

For Coccidia infection among the wildlife in R.N.P., the bushbuck (Tragelaphus scriptus) had the highest prevalence (45.5\%) (5/11), with $95 \% \mathrm{CI} \pm 29.43$ whereas the spotted hyaena (Crocota crocota) showed the lowest prevalence $(2.9 \%)(1 / 34)$, with $95 \% \mathrm{CI} \pm 5.64$ (Table 5). Area-wise, Kafiakingi showed the highest prevalence of coccidian oocysts (16\%) (29/181), with 95\% CI \pm 5.34 , and Alhufra showed the lowest prevalence (6.8\%) $(5 / 74)$, with $95 \% \mathrm{CI} \pm 5.74$. The univariate analysis using chi square, species was significantly associated (p-value $=$ 0.000 ) with floatation and sedimentation methods of identification for Coccidia infection. However, area was not significantly associated $(\mathrm{p}$-value $=0.342$ ) with floatation and sedimentation methods of identification for Coccidia infection. 
Assit Vet. Med. J. Vol. 60 No. 141 April 2014

Table 5: Univariate associations of factors with Coccidia infection positivity in Radom National Park, South Darfur State, Sudan.

\begin{tabular}{|c|c|c|c|c|c|c|c|}
\hline $\begin{array}{l}\text { Risk Factors } \\
\text { With levels }\end{array}$ & $\begin{array}{c}\text { No. of } \\
\text { tested } \\
\text { Samples }\end{array}$ & $\begin{array}{c}\text { No. of } \\
\text { positive } \\
\text { Samples }\end{array}$ & $\begin{array}{c}\% \text { Positive } \\
\text { (Prevalence) }\end{array}$ & $95 \%$ CI & d.f & $X^{2}$ & P. value \\
\hline \multicolumn{8}{|l|}{ Types: } \\
\hline Wildlife & 579 & 70 & 12.1 & \pm 2.66 & 1 & 2.346 & 0.126 \\
\hline Species: & & & & & 17 & 162.325 & 0.000 \\
\hline Warthog & 75 & 0 & 0 & 0 & & & \\
\hline Baboons & 83 & 0 & 0 & 0 & & & \\
\hline Patas monkey & 37 & 0 & 0 & 0 & & & \\
\hline Velvet monkey & 35 & 4 & 11.4 & \pm 10.53 & & & \\
\hline Leopard & 12 & 0 & 0 & 0 & & & \\
\hline Reedbuck & 17 & 6 & 35.3 & \pm 22.72 & & & \\
\hline Cheetah & 27 & 0 & 0 & 0 & & & \\
\hline Aardvank & 15 & 4 & 26.7 & \pm 22.39 & & & \\
\hline Dikdik & 101 & 28 & 27.7 & \pm 8.73 & & & \\
\hline Rabbit & 69 & 13 & 18.8 & \pm 9.22 & & & \\
\hline Fox & 41 & 3 & 7.3 & \pm 7.96 & & & \\
\hline Spotted hyaena & 34 & 1 & 2.9 & \pm 5.64 & & & \\
\hline Bushbuck & 11 & 5 & 45.5 & \pm 29.43 & & & \\
\hline Waterbuck & 22 & 6 & 27.3 & \pm 18.62 & & & \\
\hline Area: & & & & & 4 & 4.507 & 0.342 \\
\hline Radom area & 352 & 38 & 10.8 & \pm 3.24 & & & \\
\hline Alhufra & 129 & 9 & 7 & \pm 4.4 & & & \\
\hline Titrbi & 184 & 16 & 8.7 & \pm 4.07 & & & \\
\hline Kafindibei & 225 & 25 & 11.1 & \pm 4.1 & & & \\
\hline Kafiakingi & 289 & 38 & 13.1 & \pm 3.89 & & & \\
\hline
\end{tabular}

Regarding prevalence of Ascaris per animal species, the bushbuck (Tragelaphus scriptus) had the highest prevalence $(18.2 \%)(2 / 11)$, with $95 \% \mathrm{CI} \pm 22.8$, while the dikdik (Madaqua guentheri) showed the lowest prevalence (1\%) (1/101), with 95\% CI \pm 1.94 (Table 6). All wildlife infected by Ascaris eggs were ruminant animals. As for the prevalence of Ascaris per site of faecal sample collection, Radom area showed the highest prevalence (1.7\%) (6/352), with $95 \% \mathrm{CI} \pm 1.35$, whereas Kafiakingi showed the lowest prevalence (1\%) (3/289), with $95 \% \mathrm{CI} \pm 1.15$. 
Assit Vet. Med. J. Vol. 60 No. 141 April 2014

Table 6: Univariate associations of factors with Ascaris infection positivity in Radom National Park, South Darfur State, Sudan.

\begin{tabular}{|c|c|c|c|c|c|c|c|}
\hline $\begin{array}{l}\text { Risk F actors } \\
\text { With levels }\end{array}$ & $\begin{array}{c}\text { No. of } \\
\text { tested } \\
\text { Samples }\end{array}$ & $\begin{array}{c}\text { No. of } \\
\text { positive } \\
\text { Samples }\end{array}$ & $\begin{array}{c}\text { \%Positive } \\
\text { (Prevalence) }\end{array}$ & $\begin{array}{c}95 \% \\
\text { CI }\end{array}$ & d.f & $X^{2}$ & P. value \\
\hline \multicolumn{8}{|l|}{ Types: } \\
\hline Wild & 579 & 3 & 0.5 & \pm 0.57 & 1 & 4.344 & 0.037 \\
\hline Species: & & & & & 17 & 92.394 & 0.000 \\
\hline Warthog & 75 & 0 & 0 & 0 & & & \\
\hline Baboons & 83 & 0 & 0 & 0 & & & \\
\hline Patas monkey & 37 & 0 & 0 & 0 & & & \\
\hline Velvet monkey & 35 & 0 & 0 & 0 & & & \\
\hline Leopard & 12 & 0 & 0 & 0 & & & \\
\hline Reedbuck & 17 & 0 & 0 & 0 & & & \\
\hline Cheetah & 27 & 0 & 0 & 0 & & & \\
\hline Aardvank & 15 & 0 & 0 & 0 & & & \\
\hline Dikdik & 101 & 1 & 1 & \pm 1.94 & & & \\
\hline Rabbit & 69 & 0 & 0 & 0 & & & \\
\hline Fox & 41 & 0 & 0 & 0 & & & \\
\hline Spotted hyaena & 34 & 0 & 0 & 0 & & & \\
\hline Bushbuck & 11 & 2 & 18.2 & \pm 22.8 & & & \\
\hline Waterbuck & 22 & 0 & 0 & 0 & & & \\
\hline Area: & & & & & 4 & 2.886 & 0.577 \\
\hline Radom area & 352 & 6 & 1.7 & \pm 1.35 & & & \\
\hline Alhufra & 129 & 0 & 0 & 0 & & & \\
\hline Titrbi & 184 & 3 & 1.6 & \pm 1.81 & & & \\
\hline Kafindibei & 225 & 2 & 0.9 & \pm 1.23 & & & \\
\hline Kafiakingi & 289 & 3 & 1 & \pm 1.15 & & & \\
\hline
\end{tabular}

The prevalence of Toxocara infection in wildlife was found to be $7.4 \%$ (43/579), with 95\% CI \pm 2.13 . Regarding the prevalence of Toxocara by animal species, the leopards (Panthera pardus) had a prevalence of 50\% (6/12), with 95\% CI \pm 28.29 , and the warthog (Phacochoerus aethiopicus) showed a lower prevalence (4\%) (3/75), with $95 \%$ CI \pm 4.43 (Table 7 ).

For the prevalence of Toxocara infection by area of faecal sample collection, Kafiakingi showed a prevalence of 4.5\% (13/289), with 95\% CI \pm 2.39 , and Alhufra showed a lower prevalence (2.3\%) (3/129), with 95\% CI \pm 2.59 . The proportions of positive results for Toxocara infection differed between species and area. In the univariate analysis using chi-square, species was significantly associated with floatation and sedimentation methods of identification ( $\mathrm{p}$-value $=0.000$ ). However, area was not significantly associated with floatation and sedimentation methods of identification for Toxocara infection ( $\mathrm{p}$-value $=0.778$ ). 
Assit Vet. Med. J. Vol. 60 No. 141 April 2014

Table 7: Univariate associations of factors with Toxocara infection positivity in Radom National Park, South Darfur State, Sudan.

\begin{tabular}{|c|c|c|c|c|c|c|c|}
\hline $\begin{array}{l}\text { Risk Factors } \\
\text { With levels }\end{array}$ & $\begin{array}{c}\begin{array}{c}\text { No. of } \\
\text { tested }\end{array} \\
\text { Samples }\end{array}$ & $\begin{array}{c}\text { No. of } \\
\text { positive } \\
\text { Samples }\end{array}$ & $\begin{array}{c}\text { \%Positive } \\
\text { (Prevalence) }\end{array}$ & $95 \% \mathrm{CI}$ & d.f & $X^{2}$ & P. value \\
\hline \multicolumn{8}{|l|}{ Types: } \\
\hline Wildlife & 579 & 43 & 7.4 & \pm 2.13 & 1 & 46.246 & 0.000 \\
\hline Species: & & & & & 17 & 390.049 & 0.000 \\
\hline Warthog & 75 & 3 & 4 & \pm 4.43 & & & \\
\hline Baboons & 83 & 0 & 0 & 0 & & & \\
\hline Patas monkey & 37 & 0 & 0 & 0 & & & \\
\hline Velvet monkey & 35 & 0 & 0 & 0 & & & \\
\hline Leopard & 12 & 6 & 50 & \pm 28.29 & & & \\
\hline Reedbuck & 17 & 0 & 0 & 0 & & & \\
\hline Cheetah & 27 & 8 & 29.6 & \pm 17.22 & & & \\
\hline Aardvank & 15 & 0 & 0 & 0 & & & \\
\hline Dikdik & 101 & 0 & 0 & 0 & & & \\
\hline Rabbit & 69 & 0 & 0 & 0 & & & \\
\hline Fox & 41 & 18 & 43.9 & \pm 15.19 & & & \\
\hline Spotted hyaena & 34 & 8 & 23.5 & \pm 14.25 & & & \\
\hline Bushbuck & 11 & 0 & 0 & 0 & & & \\
\hline Waterbuck & 22 & 0 & 0 & 0 & & & \\
\hline Area: & & & & & 4 & 1.772 & 0.778 \\
\hline Radom area & 352 & 11 & 3.1 & \pm 1.81 & & & \\
\hline Alhufra & 129 & 3 & 2.3 & \pm 2.59 & & & \\
\hline Titrbi & 184 & 8 & 4.3 & \pm 2.93 & & & \\
\hline Kafindibei & 225 & 8 & 3.6 & \pm 2.43 & & & \\
\hline Kafiakingi & 289 & 13 & 4.5 & \pm 2.39 & & & \\
\hline
\end{tabular}

Concerning the prevalence of Haemonchus by animal species, the reedbuck (Redunca redunca) had a prevalence of $17.6 \%$ (3/17), with $95 \% \mathrm{CI} \pm 18.1$ (Table 8). As far as the area of sampling is concerned, Radom area showed the highest prevalence of Haemonchus (2.6\%) (9/352), with 95\% CI \pm 1.66 , while Alhufra showed the lowest prevalence $(0.8 \%)(1 / 129)$, with $95 \% \mathrm{CI} \pm 1.54$. In the univariate analysis using chi-square, species (p-value $=$ 0.000 ) was significantly associated with floatation and sedimentation methods of identification for Haemonchus infection. However, area ( $\mathrm{p}$-value $=0.135)$ was not significantly associated with floatation and sedimentation methods of identification for this parasite. 
Assit Vet. Med. J. Vol. 60 No. 141 April 2014

Table 8: Univariate associations of factors with Haemonchus infection positivity in Radom National Park, South Darfur State, Sudan.

\begin{tabular}{|c|c|c|c|c|c|c|c|}
\hline $\begin{array}{l}\text { Risk Factors } \\
\text { With levels }\end{array}$ & $\begin{array}{c}\text { No. of } \\
\text { tested } \\
\text { Samples }\end{array}$ & $\begin{array}{c}\text { No. of } \\
\text { positive } \\
\text { Samples }\end{array}$ & $\begin{array}{c}\text { \%Positive } \\
\text { (Prevalence) }\end{array}$ & $\begin{array}{c}95 \% \\
\text { CI }\end{array}$ & d.f & $X^{2}$ & P. value \\
\hline \multicolumn{8}{|l|}{ Types: } \\
\hline Wildlife & 579 & 5 & 0.9 & \pm 0.77 & 1 & 2.07 & 0.150 \\
\hline Species: & & & & & 17 & 71.988 & 0.000 \\
\hline Warthog & 75 & 0 & 0 & 0 & & & \\
\hline Baboons & 83 & 0 & 0 & 0 & & & \\
\hline Patas monkey & 37 & 0 & 0 & 0 & & & \\
\hline Velvet monkey & 35 & 0 & 0 & 0 & & & \\
\hline Leopard & 12 & 0 & 0 & 0 & & & \\
\hline Reedbuck & 17 & 3 & 17.6 & \pm 18.1 & & & \\
\hline Cheetah & 27 & 0 & 0 & 0 & & & \\
\hline Aardvank & 15 & 0 & 0 & 0 & & & \\
\hline Dikdik & 101 & 2 & 2 & \pm 2.73 & & & \\
\hline Rabbit & 69 & 0 & 0 & 0 & & & \\
\hline Fox & 41 & 0 & 0 & 0 & & & \\
\hline Spotted hyaena & 34 & 0 & 0 & 0 & & & \\
\hline Bushbuck & 11 & 0 & 0 & 0 & & & \\
\hline Waterbuck & 22 & 0 & 0 & 0 & & & \\
\hline Area: & & & & & 4 & 7.012 & 0.135 \\
\hline Radom area & 352 & 9 & 2.6 & \pm 1.66 & & & \\
\hline Alhufra & 129 & 1 & 0.8 & \pm 1.54 & & & \\
\hline Titrbi & 184 & 0 & 0 & 0 & & & \\
\hline Kafindibei & 225 & 2 & 0.9 & \pm 1.23 & & & \\
\hline Kafiakingi & 289 & 4 & 1.4 & \pm 1.35 & & & \\
\hline
\end{tabular}

The prevalence of Oesophagostomum helminth parasites in the wildlife in the study areas was found to be $0.9 \%$ (5/579), with 95\% CI \pm 0.77 , with warthog (Phacochoerus aethiopicus) showing the highest prevalence (4\%) (3/75) while Patas monkeys (Erythrocebus patas) showed the lowest prevalence (2.7\%) (1/37), with 95\% $\mathrm{CI} \pm 5.22$ (Table 9). Considering the prevalence of Oesophagostomum by area of faecal sample collection, Radom area showed the highest prevalence (6.5\%) (23/352), with $95 \% \mathrm{CI} \pm 2.58$, in contrast to Titrbi which showed the lowest prevalence (1.6\%) (3/184), with $95 \% \mathrm{CI} \pm 1.81$. In the univariate analysis using chi-square, species (pvalue $=0.000)$ was significantly associated with floatation and sedimentation methods of identification for Oesophagostomum infection. However, area ( $\mathrm{p}$-value $=0.010$ ) was not significantly associated with floatation and sedimentation methods of identification for this parasite. 
Table 9: Univariate associations of factors with Oesophagostomum infection positivity in Radom National Park, South Darfur State, Sudan.

\begin{tabular}{|c|c|c|c|c|c|c|c|}
\hline $\begin{array}{l}\text { Risk Factors } \\
\text { With levels }\end{array}$ & $\begin{array}{c}\text { No. of } \\
\text { tested } \\
\text { Samples }\end{array}$ & $\begin{array}{c}\text { No. of } \\
\text { positive } \\
\text { Samples }\end{array}$ & $\begin{array}{c}\text { \%Positive } \\
\text { (Prevalence) }\end{array}$ & $\begin{array}{c}95 \% \\
\text { CI }\end{array}$ & d.f & $X^{2}$ & P. value \\
\hline \multicolumn{8}{|l|}{ Types: } \\
\hline Wildlife & 579 & 5 & 0.9 & \pm 0.77 & 1 & 24.121 & 0.000 \\
\hline Species: & & & & & 17 & 90.106 & 0.000 \\
\hline Warthog & 75 & 3 & 4 & \pm 4.43 & & & \\
\hline Baboons & 83 & 0 & 0 & 0 & & & \\
\hline Patas monkey & 37 & 1 & 2.7 & \pm 5.22 & & & \\
\hline Velvet monkey & 35 & 0 & 0 & 0 & & & \\
\hline Leopard & 12 & 0 & 0 & 0 & & & \\
\hline Reedbuck & 17 & 0 & 0 & 0 & & & \\
\hline Cheetah & 27 & 0 & 0 & 0 & & & \\
\hline Aardvank & 15 & 0 & 0 & 0 & & & \\
\hline Dikdik & 101 & 1 & 1 & \pm 1.94 & & & \\
\hline Rabbit & 69 & 0 & 0 & 0 & & & \\
\hline Fox & 41 & 0 & 0 & 0 & & & \\
\hline Spotted hyaena & 34 & 0 & 0 & 0 & & & \\
\hline Bushbuck & 11 & 0 & 0 & 0 & & & \\
\hline Waterbuck & 22 & 0 & 0 & 0 & & & \\
\hline Area: & & & & & 4 & 13.241 & 0.010 \\
\hline Radom area & 352 & 23 & 6.5 & \pm 2.58 & & & \\
\hline Alhufra & 129 & 3 & 2.3 & \pm 2.59 & & & \\
\hline Titrbi & 184 & 3 & 1.6 & \pm 1.81 & & & \\
\hline Kafindibei & 225 & 6 & 2.7 & \pm 2.12 & & & \\
\hline Kafiakingi & 289 & 7 & 2.4 & \pm 1.76 & & & \\
\hline
\end{tabular}

For the prevalence of Trichostrongylus spp., the overall prevalence in wildlife in RNP was $10.2 \%(59 / 579)$ (Table 10). The Patas monkey (Erythrocebus patas) had the highest prevalence (37.8\%) (14/37) in contrast to the warthog (Phacochoerus aethiopicus) which showed the lowest prevalence (2.7\%) (2/75). Some animal species such as Lepus capensis (rabbits), Canis adustus (foxes), Crocota crocota (spotted hyaena) and Tragelaphus scriptus (bushbuck) showed no infection with any helminth or protozoal parasite at all. Moreover, the primates, Cercopithecus aethiops (vervet monkey) and Erythrocebus patas (Patas monkeys), recorded the highest prevalence of Trichostrongylus infection than all other animal species examined throughout this investigation. Animals in Radom area, Kafiakingi and Kafindibei showed the highest prevalence $14.5 \%, 14.5 \%$ and $14.2 \%$, respectively, while those in Alhufra, on the other hand, showed the lowest prevalence (10.1\%). 
Table 10: Univariate associations of factors with Trichostrongylus infection positivity in Radom National Park, South Darfur State, Sudan.

\begin{tabular}{|c|c|c|c|c|c|c|c|}
\hline $\begin{array}{l}\text { Risk Factor } \\
\text { With levels }\end{array}$ & $\begin{array}{l}\text { No. of } \\
\text { tested } \\
\text { Samples }\end{array}$ & $\begin{array}{l}\text { No. of } \\
\text { positive } \\
\text { Samples }\end{array}$ & $\begin{array}{l}\text { \% Positive } \\
\text { (Prevalence) }\end{array}$ & 95\% CI & d.f & $X^{2}$ & P. value \\
\hline \multicolumn{8}{|l|}{ Types: } \\
\hline Wildlife & 579 & 59 & 10.2 & \pm 2.47 & 1 & 10.109 & 0.001 \\
\hline Species: & & & & & 17 & 116.763 & 0.000 \\
\hline Warthog & 75 & 2 & 2.7 & \pm 3.67 & & & \\
\hline Baboons & 83 & 19 & 22.9 & \pm 9.04 & & & \\
\hline Patas monkey & 37 & 14 & 37.8 & \pm 15.62 & & & \\
\hline Velvet monkey & 35 & 13 & 37.1 & \pm 16 & & & \\
\hline Leopard & 12 & 0 & 0 & 0 & & & \\
\hline Reedbuck & 17 & 2 & 11.8 & \pm 15.34 & & & \\
\hline Cheetah & 27 & 0 & 0 & 0 & & & \\
\hline Aardvank & 15 & 0 & 0 & 0 & & & \\
\hline Dikdik & 101 & 6 & 5.9 & \pm 4.6 & & & \\
\hline Rabbit & 69 & 0 & 0 & 0 & & & \\
\hline Fox & 41 & 0 & 0 & 0 & & & \\
\hline Spotted hyaena & 34 & 0 & 0 & 0 & & & \\
\hline Bushbuck & 11 & 0 & 0 & 0 & & & \\
\hline Waterbuck & 22 & 3 & 13.6 & \pm 14.32 & & & \\
\hline Area: & & & & & 4 & 3.052 & 0.549 \\
\hline Radom area & 352 & 51 & 14.5 & \pm 3.68 & & & \\
\hline Alhufra & 129 & 13 & 10.1 & \pm 5.2 & & & \\
\hline Titrbi & 184 & 20 & 10.9 & \pm 4.5 & & & \\
\hline Kafindibei & 225 & 32 & 14.2 & \pm 4.56 & & & \\
\hline Kafiakingi & 289 & 42 & 14.5 & \pm 4.06 & & & \\
\hline
\end{tabular}

\section{DISCUSSION}

In the present study, 14 wildlife species in Radom National Park (R.N.P.), South Darfur State (Sudan) were investigated for gastrointestinal helminthes by examination of faecal samples. Of the several gastrointestinal tract (GIT) nematodes recorded, Trichostrongylus and Strongyloides spp. represented the highest and most prevalent helminth parasites among the wildlife investigated in the present study. The prevalence of Trichostrongylus spp. reported in the present study is in agreement with that reported in wildlife kept at Khartoum Zoo (Sudan) by Saad et al. (1983) in faeces of dorcas gazelles, Indian cheetah, roan antelope, giraffe, red-fronted gazelles, Nubis baboons, vervet monkeys and cape buffaloes. It was also reported in guenons (Cercopithecus spp.) of western Uganda by Thomas et al. (2004). The present study reported that Trichostrongylus spp. was the most predominant parasite in Patas monkeys (Erythrocebus patas) in Radom area and Kafiakingi.

The present study confirmed the presence of Ascaris spp. as the most predominant parasite in bushbuck (Tragelaphus scriptus) in Radom area. Ascaris worms are known to have a wide range of hosts and were formerly reported in waterbuck in Lake Mburo National Park in Uganda (Ocaido et al., 2004).

The prevalence of Toxocara parasites in the study area was higher $(63.51 \%)$ in the rainy season as compared to the winter season $(50 \%)$. The first report of Toxocara cati in wildlife was in the leopard (Panthera pardus saxicolor) in Iran and was 
documented by Esfandiari et al. (2010). It was also reported in the tiger, lion, leopard and jungle cat in India (Mahali et al., 2010). Toxocara worms were recovered in the faeces of Nubis baboons, Hussar monkeys, Asmara gazelle and lion by Saad et al. (1983) who reported the same parasite in a tiger and a lion in Khartoum Zoo, Sudan. Similar results were also recorded in the present study in which Toxocara eggs were reported in leopards (Panthera pardus) in Kafiakingi where these worms had the highest prevalence in leopards (50\%) than in other animals in the study area. It worths mentioning that Kafiakingi was more populated with feline and canine animals compared to the other remaining four study sites.

The results of this study recorded that Haemonchus spp. was the most predominant parasite of reedbuck (Redunca redunca) in Radom area. The samples collected from reedbuck were few (only 17) which might be the reason that the reedbuck represented the highest percentage of infection. Haemonchus spp. was reported as the most predominant parasite in mountain Reedbuck (Redunca fulvorufula) in South Africa (Boomker et al., 1989). It was also reported in the Loskop Dam Nature Reserve and the Mountain Zebra National Park (Boomker et al., 1983) in South Africa. Haemonchus contortus is a cosmopolitan helminth parasite of sheep and goats (Chaudary et al., 2007). It was also reported in blue wildebeest and $K u d u$ in South Africa (Van Wyk and Boomker, 2011). The different species of genus Haemonchus had a wide range of domestic and wildlife animal hosts as it is a known and widely spread ruminant parasite (Soulsby, 1982).

Oesophagostomum spp. was reported as the most predominant parasite in cattle in the neighboring Abyei area, South-western Sudan (Idriss et al., 2012). Oesophagostomum eggs were found in the faeces of warthog (Phacochoerus aethiopicus) in Dinder National Park (Sudan) by Dunn (1978). Also Oesophagostomum dentatum was reported as a helminth of swine. Oesophagostomum macombiquei was described from 9 females of warthog (Phacochoerus aethiopicus) by Boomker (1990) in northern Mozambique. Also Oesophagostomum spp. was reported in water buffaloes in Bangladesh (Islam et al., 1992).

The presence of Trichuris worms in olive and chacma baboon is commonly reported in Africa by Kuntz and Myers (1966), Kuntz and Myers (1967), Eley et al. (1989), McGrew et al. (1989), Muller et al. (1996), Munene et al. (1998), Murray et al. (2000), Hahn et al. (2003), Ocaido et al. (2003), Hope et al. (2004) and Legesse and Erko (2004). The present study confirmed that Trichuris spp. was the most predominant parasite of baboons (Papio cynocephius) in Radom area. Trichuris spp. is known to infect different species of animals including man.
In a previous study conducted in Dinder National Park by Sayied and Agab (2009), Moniezia spp. was reported as the most predominant parasite in the park where it is noticed that the degree of this tapeworm (Moniezia spp.) infection in the warthog was higher $(22 \%)$ than in the other wildlife species investigated in the Dinder National Park, namely, reedbucks (15.8\%), waterbucks (13\%) and buffaloes (6.9\%). In Iran, Moniezia expansa was also reported in the goitered gazelle which were harbouring cestode and nematode worms (Eslami et al., 1981). The results of the present study confirmed that Moniezia spp. was the most predominant parasite in warthog (Phacochoerus aethiopicus) in Kafiakingi. However, Moniezia spp. had the highest prevalence (44\%) in warthog than in other animals investigated in the study area, possibly due to differences and uniqueness in feeding behavior of the warthog.

Coccidia spp. was reported as the most predominant parasite in bushbuck in South Western Uganda (Apio and Wronski, 2004). Sayied and El Mubarak (2007) recorded a high infection rate with this protozoan parasite in other wildlife species in DNP including baboons, buffaloes and waterbucks. In a more recent survey, coccidian oocysts were also detected in the faeces of all wild animals in Dinder National Park by Sayied and Agab (2009). Unlike the previous reports, the present study demonstrated that Coccidia oocysts had the highest prevalence in bushbuck (Tragelaphus scriptus) whereas the spotted hyaena (Crocota crocota) showed the lowest prevalence which may be due to the differences in the feeding behavior of the two types of animals.

The high prevalence of helminth parasites recorded among wildlife in this investigation necessitates the need to design and implement a control policy of helminths parasites in wild animals as well as adoption of a control policy in the domestic animals which were frequently found co-grazing with the wildlife in Radom National Park.

\section{ACKNOWLEDGEMENTS}

The technical assistance of Mr. S. A. Noja is greatly acknowledged. Due thanks are extended to Nyala Veterinary Research Laboratory Staff for their help and encouragement. Special acknowledgement and great appreciation for the General Administration of Wildlife Protection personnel, Nyala, Region, for help in wildlife faeces identification and for field guidance and orientation.

\section{REFERENCES}

Apio, A. and Wronski, T. (2004): Post-parturient changes in faecal helminthes eggs and Coccidian oocysts count of a Bushbuck (Tragelaphus scriptus) in Queen Elizabeth 
National Park. South Western Uganda. Helminthologia. Vol. 41 (3): 135-138.

Boomker, J. (1990): Parasites of South African Wildlife. V.A. Description of the males of Oesophagostomum mocambiquei (Ortlepp, 1964) from warthogs (Phacochoerus aethiopicus) (Pallas, 1766). J. Vet. Res., 57(3): 169-173.

Boomker, J.; Horak, I.G.; Flamand, J. and Keep, M.E. (1989): Parasites of South African Wildlife. Helminths of common reedbuck (Redunca arundinum) in Natal. Journal of Veterinary Research. Vol. 56(1): 51-7.

Boomker, J.; Du Plessis, W.H. and خطأ مرجع الارتباط: Boomker, E.A. (1983): Some helminth and arthropod parasites of the grey duiker (Sylvicapra grimmia). Journal of Veterinary Research. Vol. 50(4): 233-41.

Chaudary, F.R.; Khani, M.F.U. and Qayyum, M. (2007): Prevalence of Haemonchus contortus in naturally infected small ruminants grazing in the Potohar Area of Pakistan. Pakistan Vet. J., 27(2): 73-79. 73.

Dunn, A.M. (1978): Textbook of Veterinary Helminthology, $2^{\text {nd }}$ edn. William Heinemann Medical Books Ltd., London.

Eisa, A.M.; El Bedawi, E.S.; Saad, M.B.; Ibrahim, A.M. and El Gezuli, A.Y. (1979): Check list and first records of helminth parasites of domestic and wild animals reported in Sudan during 1902-1975. Sud. J. Vet. Res. (1): 5563.

Esfandiari, I.B.; Youssefi, M.R. and Tabari, M. A. (2010): First Report of Toxocara cati in Persian Leopard (Panther pardussaxicolor) in Iran. Global Veterinaria. Vol. 4 (4): 394-395.

Eley, R.M.; Strum, S.C.; Muchemi, G. and Reid, G.D.F. (1989): Nutrition, body condition, activity patterns and parasitism of freeranging baboons (Papio anubis) in Kenya. American Journal of Primatology. 18: 209-219.

Esfandiari, I.B.; Youssefi, M.R. and Tabari, M.A. (2010): First Report of Toxocara cati in Persian Leopard (Panther pardussaxicolor) in Iran. Global Veterinaria. Vol. 4 (4): 394-395.

Eslami, A.; Rahbari, S. and Meydani, M. (1981): Cestodes and trematodes of wild sheep (Ovis ammon orientalis) and goitered gazelle (Gazella subgutturosa) in Iran. Vet. Parasitology. 8: 99-101.

FAO (2006): Techniques for parasite assays and identification in faecal samples. Management of vertisols in Sub-Saharan Africa. Proceedings of Conference.

Hahn, N.E.; Proulx, D.; Muruthi, P.M.; Alberts, S. and Altmann, J. (2003): Gastrointestinal parasites in free-ranging Kenyan baboons (Papio cynocephalus and P. anubis).
International Journal of Primatology. 24 (2): 271-279.

Hope, K.; Goldsmith, M.L. and Graczyk, T. (2004): Parasitic health of olive baboons in Bwindi Impenetrable National Park, Uganda. Vet. Parasitology. 122 (2): 165-170.

Idriss, B.G.; Atif, E.A. and Khitma, H.E. (2012): Study on prevalence of parasitic diseases in cattle in Abyei Area, Sudan. Journal of Cell and Animal Biology. Vol. 6(6): 88-98.

Islam, F.M.S.; Rahman, M.H. and Chowdhury, S.M.Z.H. (1992): Prevalence of parasites of water buffaloes in Bangladesh. Animal Health Research Division, Vol.5 (4): 601-604.

IUCN (1987): International Union for Conservation of Nature. Radom Bird Life Data Zone, 6811.

Kuntz, R.E. and Myers, B.J. (1966): Parasites of baboons (Papio doguera [Pucheran,1856]) captured in Kenya and Tanzania, East Africa. Primates 7: 27-32.

Kuntz, R.E. and Myers, B.J. (1967): Parasites of the Kenya baboon: arthropods, blood protozoa and helminthes (Kenya 1966). Primates. 8: 75-82.

Legesse, M. and Erko, B. (2004): Zoonotic intestinal parasites in Papio anubis (baboon) and Cercopithecus aethiops (vervet) from four localities in Ethiopia. Acta Tropica. 90 (3): 231-236.

Mahali, A.K.; Panda, D.N.; Panda, M.R.; Mohanty, B.N. and Sahoo, N. (2010): Incidence and seasonal variation of gastro-intestinal parasitic infections in captive carnivores in Nandankanan Zoological Park, Orissa. Journal of Vet. Parasitology. Vol. 24 (2): $111-115$.

McGrew, W.C.; Tutin, C.E.G.; Collins, D.A. and File, S.K. (1989): Intestinal parasites of sympatric Pan troglodytes and Papio spp. at two sites: Gombe (Tanzania) and Mt. Assirik (Senegal). American Journal of Primatology. 17: 147-155.

Muller, C.D.M.; Collins, D.A. and Woolhouse, M.E.J. (1996): Intestinal parasite burden in five troops of olive baboons (Papio cynanocephalus anubis) in Gombe Stream National Park, Tanzania. Parasitology. 112: 489-497.

Munene, E.; Otsyula, M.; Mbaabu, D.A.N.; Mutahi, W.T.; Muriuki, S.M.K. and Muchemi, G.M. (1998): Helminth and protozoan gastrointestinal tract parasites in captive and wild-trapped African non-human primates. Vet. Parasitology, 78: 195-201.

Murray, S.; Stem, C.; Boudreau, B. and Goodall, J. (2000): Intestinal parasites of baboons (Papio cynocephalus anubis) and chimpanzees (Pan troglodytes) in Gombe National Park. Journal of Zoo and Wildlife Medicine. 31(2): $176-178$ 
Ocaido, M.; Dranzoa, C. and Cheli, P. (2003): Gastrointestinal parasites of baboons (Papio anubis) interacting with humans in West Bugwe Forest Reserve, Uganda. Africa Journal of Ecology. 41: 356-359.

Ocaido, M.; Serifert, L. and Baranga, J. (2004): Helminth risks associated with mixed game and livestock interactions in and around Lake Mburo National Park, Uganda. Afr. J. Ecol., 42: 42-48.

Saad, M.B. and Eisa, A.M. (1980): Helminth parasites of the Hussar monkeys (Erythrocebus patas) from Khartoum Zoo. Sud. J. Vet. Sci. Anim. Husb., 2: 101.

Saad, M.B.; El Mubarak, K.A. and El Badawi, K.S. (1983): Endoparasites in wild animals in Khartoum Zoo. Bull. Anim. Hlth. Prod. Afr. (31): 9-15.

Sayied, A.S. and Agab, H. (2009): Wildlife Helminths Risk in Dinder National Park,
Sudan. Sudan Academy of Sciences J. (2009) (1): 7-22.

Sayied, A.S. and El Mubarak, A.K. (2007): Preliminary survey of endoparasitic infestation in wildlife in Dinder National Park (Sudan). Juba University J. of Arts and Sciences. Vol. 6: 9-23.

Soulsby, E.J.L. (1982): Helminths, Arthropods and Protozoa of Domesticated Animals. $7^{\text {th }}$ ed. Lea and Febiger, Philadelphia, Pennsylvania, 809 pp.

Thomas, R.; Gillespie, E.; Greiner, C. and Chapman, C.A. (2004): Gastrointestinal parasites of the guenons of Western Uganda. J. Parasit. 90 (6): 1356-1360.

Van Wyk, I.C. and Boomker, J. (2011): Parasites of South African wildlife. The prevalence of helminths in some common antelopes, warthogs and a bush pig in the Limpopo Province, South Africa. J. Vet. Res., Vol.78 (1): 308. Cape Town.

\section{مهددات الإحتثار الطفيلي الداخلي في الحيوانات البرية في حظيرة الردوم ، ولاية جنوب دارفور ، السودان

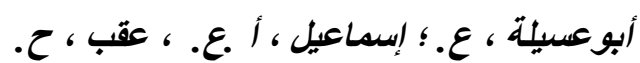 \\ E.mail: atifabuessailla@yahoo.com ,E.mail: hamidagab1@hotmail.com}

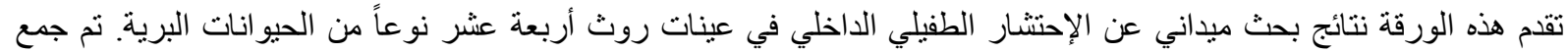

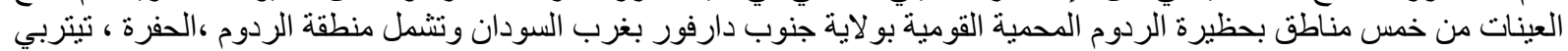

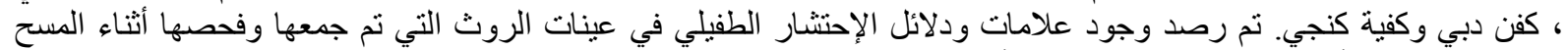
الميداني من جميع أنواع الحيو انات البرية. وجد أن ونئ من بين

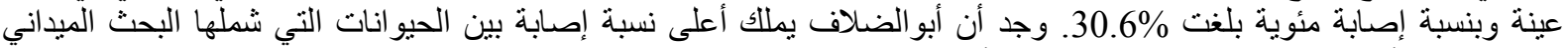

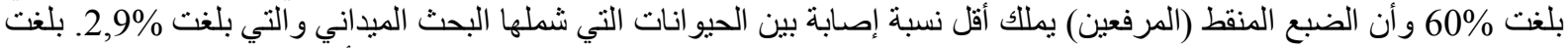

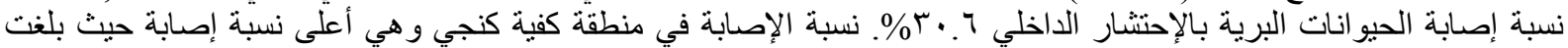

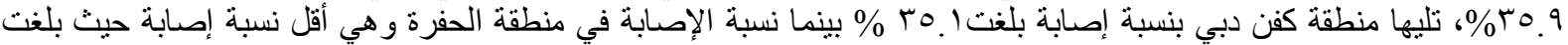

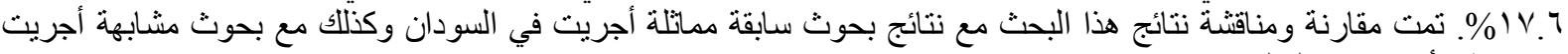
في مناطق أخرى من العالم. 